\title{
DEATH OF LEAGUE DEPUTY SECRETARY-GENERAL
}

On 24 June 1973, Mr. Nedim Abut, Deputy Secretary-General of the League of Red Cross Societies, died suddenly. After fulfilling important functions with the Turkish Red Crescent from 1946 onwards and representing the Turkish Government at various international conferences, including the 1949 Geneva Diplomatic Conference, he took part in the work of several commissions and consultative committees of the League before being appointed, in 1962, Under Secretary-General of that institution. Four years later he was appointed Deputy Secretary-General, in which capacity he has carried out several missions in various parts of the world.

The International Committee will not forget $\mathrm{Mr}$. Abut and expresses its sympathy to the League on its loss of such a valuable colleague.

\section{INTERNATIONAL RED CROSS ASSISTANCE IN INDO-CHINA}

\section{Special projects}

In addition to programmes of direct assistance to displaced persons and the particularly distressed populations in the Republic of Vietnam, the Khmer Republic and Laos, which we mentioned last month, the Indo-China Operational Group has prepared several "special projects" in co-operation with the Red Cross in the countries concerned. Some of those projects are in progress, such as the improving of the Phnom Penh pediatric centre, the medico-social action in orphanages in the Republic of Vietnam, and the supply of medicaments and medical and surgical equipment to the Pathet Lao, the Democratic Republic of Vietnam and the Provisional Revolutionary Government. Other projects in the IOG programme are: 